\title{
Odcudzená práca: dedičstvo klasického konceptu a možnosti jeho revitalizácie ${ }^{1}$
}

\author{
Daniel Gerbery ${ }^{2}$ \\ Katedra sociológie, Filozofická fakulta Univerzity Komenského v Bratislave \\ Alienated Work: A Legacy of Classical Concept and Possibilities for its Revitalization. \\ The paper focuses on alienated work, a classical sociological concept which attracted a lot of \\ attention. It discusses its roots in Marx's works, its dimensions, and issues of essentialism \\ and human nature. Against the background of the great variety of approaches to alienated \\ work in the $20^{\text {th }}$ century, attention is paid to systematization and review of main arguments \\ both in theoretical and empirical studies, with the emphasis on the Marxist interpretations. \\ High level of abstraction, difficulty with empirical validation on the one hand and loss of \\ critical power and normativity through use in empirical surveys on the other hand belonged \\ to the most frequent challenges discussed so far. The article explores a possibility how \\ critical social theory could contribute to the revitalization of the concept of alienated work. It \\ focuses on the arguments of Axel Honneth regarding work, including his early critique of \\ Habermas and his later treatment of work within the theory of recognition. \\ Sociológia 2020, Vol. 52 (No. 5: 432-451) \\ https://doi.org/10.31577/sociologia.2020.52.5.18
}

Key words: Alienation; work; market; Marxism; critical social theory

\section{Úvod}

Odcudzenie patrí ku klasickým konceptom sociológie, ktoré umožnili diagnostikovat' nástrahy modernej spoločnosti. S jeho pomocou sociológia nasvietila odvrátenú stranu postupujúcej racionalizácie a individualizácie, ako aj odstredivé sily generované rozpínajúcou sa logikou trhového mechanizmu, ktorá si nárokovala univerzálnu platnost' naprieč rôznymi inštitucionálnymi sférami. Svet (platenej) práce sa stal prirodzenou a dominantou sférou uplatnenia konceptu odcudzenia, ked’že bol klúčovým zdrojom osobnej a sociálnej identity, ako aj sociálnych skúseností (Mareš 2004). Zabudnút' však netreba ani na určujúci vplyv Marxa, ktorý síce rozoznával rôzne aspekty odcudzenia, ale za ich zdroj a zároveň bod konvergencie považoval práve odcudzenú prácu (Mészáros 1970).

Koncept odcudzenej práce dosiahol vrchol popularity $\mathrm{v}$ šest'desiatych a sedemdesiatych rokoch dvadsiateho storočia, ked' prebiehali intenzívne diskusie o jeho teoretických základoch a ked' sa stal objektom mnohých empirických výskumov. A hoci sa neskôr zdalo, že samotná idea odcudzenia akoby stratila schopnost' sprostredkovat' sociálnu a kultúrnu kritiku novo sa

\footnotetext{
1 Štúdia vznikla ako súčast' riešenia výskumného projektu Práca ako zdroj sociálneho vylúčenia a anómie: formy prekarizácie práce a ich konzekvencie (VEGA 1/0378/19).

2 Korešpondencia: Daniel Gerbery, PhD, Katedra sociológie, Filozofická fakulta Univerzita Komenského v Bratislave, Gondova 2,81491 Bratislava. Email: daniel.gerbery@uniba.sk
} 
objavujúcich spôsobov života a príbehov, ktoré ich rámcujủ ${ }^{3}$, odcudzená práca zostala nad’alej dôležitou témou (nielen) sociologického uvažovania. Ešte v polovici osemdesiatych rokov dvadsiateho storočia Kai Erikson, vtedajší predseda Americkej sociologickej asociácie, venoval svoj príhovor práve odcudzeniu vo svete práce (Erikson 1986). Nešlo pritom o sondu do dejín sociologického myslenia, ale o formuláciu otázok, na ktoré by mala sociológia v súvislosti s odcudzenou prácou d'alej hl'adat' odpovede. Avšak celistvejšie uvažovanie o fundamentoch samotného konceptu neskôr ustúpilo do úzadia, a to $\mathrm{v}$ prospech partikulárnych tém, ktoré často súviseli so skúmaním výkonu konkrétnych profesií.

Štúdia vychádza z predpokladu, že uvažovat' o odcudzenej práci má v súčasnosti stále zmysel, ak dokonca nepripustíme, že toto uvažovanie je naliehavejšie než v minulosti. Práca je stále klúčcovým zdrojom identít a sociálneho statusu a jej normatívna naliehavost' sa nestráca, skôr naopak. Spoločenské očakávania spojené $\mathrm{s}$ platenou prácou vedú $\mathrm{k}$ tomu, že existencia mimo trhu práce je často vnímaná ako zlyhanie a patologický jav. Zároveň svet práce prechádza zásadnými zmenami. Meniaca sa povaha a náplň pracovných činností, volatilita trhu práce, rastúci dôraz na flexibilitu, prekarizácia celých tried zamestnaní predstavujú len niektoré zo symptómov. Vytvárajú sa tak podmienky pre vznik napätia medzi normatívnym (a existenčným) imperatívom platenej práce a jej obsahom a konzekvenciami.

Koncept odcudzenej práce umožňuje zachytit' tieto skutočnosti v širších súvislostiach, a je preto škoda, že v súčasnom uvažovaní o práci a jej podmienkach sa používa zriedka ${ }^{4}$. Upriamuje totiž pozornost' na spôsoby, akými sa z práce stáva vec stojaca mimo našu kontrolu, cudzí element v našich životných projektoch. Pomáha uchopit' to, ako sa vztahujeme $\mathrm{k}$ práci, i to, ako táto skutočnost' formuje náš vzt’ah k svetu, k ostatným l'ud'om, aj k sebe samým. Čo je dôležité, neodkazuje len k vnútornému prežívaniu jednotlivca, ale pokrýva celú škálu sociálne štrukturovaných, normatívne vymedzených, očakávaných a vynucovaných skutočností a podmienok, ktoré spoluvytvárajú svet práce jeho formu i obsah.

Ciel'om predkladanej štúdie je preskúmat' možnosti revitalizácie a aktualizácie konceptu odcudzenej práce. Pozornost' je venovaná analýze doterajších debát v spoločenských vedách a pokusu o systematizáciu hlavných argumentov. Na to nadväzuje analýza možností, ktoré poskytuje kritická teória spoločnosti, a to konkrétne v podobe teórií Axela Honnetha, jedného z jej hlavných

\footnotetext{
3 Rahel Jaeggi v tejto súvislosti konštatuje, že filozofické základy konceptu odcudzenia pôsobili vo veku postmoderny zastaralo a jeho politické implikácie boli v období politického liberalizmu spochybnené (Jaeggi 2014: ix).

4 Je to spôsobené, okrem iného, aj tým, že na prácu sa primárne nazerá technokraticky, manažérsko-politicky - optikou ne/fungovania trhu práce, ktorého úspechy a zlyhania sú vzt’ahované k agregovaným mieram zamestnanosti či nezamestnanosti. Skúsenost' l’udí s prácou, vzt’ahovanie sa $\mathrm{k}$ práci, význam práce $\mathrm{v}$ životných projektoch a ich spoločenské predpoklady, či determinanty stoja bokom záujmu.
} 
predstavitel’ov. Kritická teória ponúka inšpiratívne nástroje diagnostiky štrukturálnych problémov vo svete práce, ktoré presahujú deskriptívny mód typický pre sociologické skúmanie práce $\mathrm{v}$ druhej polovici dvadsiateho storočia. A hoci sú jej prístupy silno ukotvené vo filozofickej tradíciín ${ }^{5}$, ciel'om je identifikovat' sociologicky relevantné argumenty, ktoré pomôžu d’alej rozvinút' sociologické uvažovanie i empirický výskum.

Text má nasledovnú štruktúru. Prvá čast' sa venuje Marxovmu poňatiu odcudzenia a odcudzenej práce, nakol'ko Marxove tézy zásadne ovplyvnili debatu v spoločenských vedách vo všeobecnosti a v kritickej teórii zvlášt'. V nasledujúcej sekcii sa pozornost' zameriava na argumenty marxistických a nemarxistických autorov dvadsiateho storočia reflektujúce Marxovo dedičstvo. V tretej časti je predmetom diskusie spôsob, akým jeden špecifický prúd kritickej teórie môže obohatit' chápanie odcudzenej práce. V závere textu sú sformulované výzvy pre d’alší výskum v danej oblasti.

\section{Marxovo poňatie odcudzenej práce}

Dejiny konceptu odcudzenia nezačínajú u Marxa ${ }^{6}$, avšak jeho dielo, a predovšetkým Ekonomicko-filozofické rukopisy, predstavujú referenčný bod mnohých debát o odcudzení a odcudzenej práci. Marx urobil z odcudzenia definičnú črtu situácie moderného človeka a vztiahol ju k spôsobu fungovania trhovej ekonomiky. Ukázal, že výsledky l'udskej činnosti - ako aj samotná l'udská činnost' - sa môžu stat' nezávislými od človeka, odcudzit' sa mu a ako také stát proti nemu ako cudzia sila. Odcudzenie sa pre Marxa stalo nielen nástrojom kritiky existujúcich podmienok, ale predovšetkým nástrojom pochopenia kapitalizmu a jeho základných mechanizmov.

Výraz odcudzenie sa vyskytuje predovšetkým v Marxových prácach zo skoršieho obdobia. To viedlo $\mathrm{k}$ dlhodobému sporu, či odcudzenie je záležitost’ou len „mladého Marxa“ alebo či predstavuje centrálnu tému jeho celého diela. Základom sporu je interpretácia zjavných odlišností medzi ranými a neskoršími textami, ktoré sa často zjednodušene popisujú ako rozdiel medzi Marxovou humanistickou filozofiou založenou na koncepte odcudzenia a odcudzenej práce a neskoršou orientáciou na ekonomickú vedu a formuláciu ekonomických zákonitostí (Clark 1991: 71). S vedomím hrubého zjednodušenia možno rozlíšit' tri skupiny argumentov. Niektorí autori chápu tento rozdiel ako prejav zásadného posunu v Marxovom uvažovaní - napríklad ako posun od filozofie založenej na úvahách o l'udskej podstate k teoretickému anti-huma-

\footnotetext{
5 Treba však dodat', že u mnohých predstavitel’ov kritickej teórie nájdeme výrazné presahy do sociologickej teórie, vrátane Honnetha, ktorý svoje analýzy stavia aj na prácach Emila Durkheima, či Talcotta Parsonsa.

6 O odcudzení v modernej spoločnosti písali napríklad Rousseau, Hegel či Kierkegaard. Pre prehl’ad vid’ Jaeggi (2014).
} 
nizmu (Althusser 2005) ${ }^{7}$. Ďalšia skupina autorov argumentuje, že je to práve koncept odcudzenia, ktorý zjednocuje na prvý pohl'ad odlišné teoretické a metodologické perspektívy (napríklad Fromm 2004; Mészárosz 1970; Ollman 1976; Sayers 2011). Tento druhý prístup dobre reprezentuje Mészárosz (1970: 22), ktorý uznáva klúčový význam Ekonomicko-filozofických rukopisov z roku 1844 pre Marxov koncept odcudzenia, avšak zároveň upozorňuje, že interpretačným rámcom musí byt' totalita Marxovej práce. Pripisovanie konceptu odcudzenia exkluzívne mladému obdobiu podla neho hrubo falzifikuje „neskoršieho“ Marxa a podrýva vnútornú koherenciu jeho práce. Po tretie, zabudnút' netreba ani na autorov, ktorí poukazujú na komplementárnost' hlavných argumentov z oboch období, prípadne ich kontinuitu. Juraj Halas (2010) v tejto súvislosti argumentuje, že Ekonomicko-filozofické rukopisy predstavovali prvý pokus o kritiku politickej ekonómie, ktorá bola dlhodobým Marxovým projektom a ktorá vyvrcholila vo vyzretej podobe omnoho neskôr v Kapitáli. Podl'a Halasa (2010: 438) už tento prvý pokus priniesol niektoré dôležité idey, ktoré sa stali súčast'ou teoretickej výbavy neskoršej kritiky politickej ekonómie. Rozdiel medzi skorším a neskorším obdobím tak nie je posunom od humanistickej filozofii $\mathrm{k}$ ekonómii, ale posunom od externej kritiky politickej ekonómie, založenej na historizácii ekonomických kategórii, $\mathrm{k}$ internej kritike, ktorá prináša nové a zároveň modifikuje existujúce kategórie ekonómie (ibid.).

Marx rozpracoval ideu odcudzenia viacerými smermi, avšak spoločným menovatel'om rôznych foriem odcudzenia sa stala odcudzená práca. Prácu chápal ako fundamentálnu aktivitu l'udského života, ako druhovú činnost' človeka - vedomú činnost', ktorá je predmetom chcenia a vedomia, a nie ako určenost', s ktorou bezprostredne splýva (Marx 1971: 71). Práca je procesom osvojovania si vonkajšieho sveta a jeho pretvárania. Prostredníctvom práce si človek vytvára vzt'ah k svetu i k iným l'ud’om, a môže menit' i sám seba. Týmto poňatím práce Marx oponoval vtedajšej ekonómii. Povahu práce neponechal bokom vedeckého záujmu ako akúsi samozrejmost', daný fakt, ktorý nepotrebuje vysvetlenie, ale tematizoval ju ako jeden z klúčových problémov modernej spoločnosti.

Odcudzenú prácu Marx približuje v známej časti Ekonomicko-filozofických rukopisov (1971: 72): „Predmet, ktorý práca vytvára, teda jej produkt, vystupuje proti práci ako cudzia bytost', ako moc nezávislá od výrobcu. Produkt práce je taká práca, ktorá sa v nejakom predmete ustálila, stala sa vecou, je to spredmetnenie práce. Uskutočňovanie práce je jej spredmetnením. Toto uskutočňovanie práce sa v ekonomickej situácii javí ako zneskutočnenie robotníka, spredmetnenie ako strata a rabstvo predmetu, privlastnenie ako odcudzenie,

\footnotetext{
7 V texte sa opierame o jedno z novších vydaní klasickej Althusserovej práce „For Marx“ z roku 2005. Pôvodne vyšla v roku 1965, v anglickom preklade v roku 1969
} 
scudzenie.“ Práca teda predstavuje proces spredmetnenia - proces, v ktorom človek zvecňuje sám seba v nejakom produkte. Medzi spredmetnením a odcudzením je však rozdiel. Marx na to poukazuje, ked' najprv píše o uskutočňovaní práce ako takom a následne o tom, akú podobu uskutočňovanie nadobúda „V ekonomickej situácii“, čím odkazuje k podmienkam kapitalistickej ekonomiky.

V uvedenom citáte Marx definuje jeden zo štyroch aspektov odcudzenej práce: odcudzenie predmetu práce. Druhým aspektom je odcudzenie pracovnej aktivity. Vzt'ah k pracovnej aktivite ako k odcudzenej aktivite súvisí s odcudzením predmetu práce: „odcudzenie sa neukazuje len vo výsledku, ale v akte samotnej produkcie, vo vnútri samotnej produkujúcej činnosti ${ }^{8 *}$ (Marx 1971: 74). Ide o seba-odcudzenie. Odcudzená pracovná aktivita predstavuje prácu, ktorá je vynútená a ktorá nie je uspokojením nejakej potreby, ale len prostriedkom na uspokojenie potrieb mimo nej. Produktívna činnost' teda ponúka uspokojenie potrieb len prostredníctvom predaja práce niekomu inému. Sama osebe neprináša potvrdenie človeka, ale popiera ho. V tomto zmysle je ilustratívna nasledujúca Marxova poznámka o povahe práce, ktorej význam dôverne pozná aj nemalá čast' súčasníkov: ,jej cudzost' sa zretel'ne prejaví $\mathrm{v}$ tom, že akonáhle neexistuje žiaden fyzický ani iný nátlak, uteká sa pred ňou ako pred morom“ (Marx 1971: 75).

Tretím aspektom je odcudzenie „druhového“ života. Marx považoval prácu za aktivitu špecifickú pre človeka. Prácou, pretváraním okolitého sveta človek potvrdzuje svoj druhový život. Tým, že odcudzená práca znamená odcudzenie pracovnej aktivity a predmetu práce - ktorý je spredmetnením práce a tým pádom aj druhového života človeka - znamená aj odcudzenie druhovému životu. Redukuje prácu ako vedomú, praktickú činnost', ktorou sa človek vzt’ahuje k sebe ako k univerzálnej a slobodnej bytosti, na nástroj čisto fyzickej existencie. Stráca sa tým charakter práce ako druhovej aktivity. Posledný aspekt odcudzenia spočíva $\mathrm{v}$ odcudzení človeka ostatným l'ud'om. Vyplýva z Marxovej klúčovej premisy, že prácou sa nevytvárajú len materiálne statky, ale prácou sa produkujú a reprodukujú aj sociálne vzt’ahy. Práca sa teda spredmetňuje aj v sociálnych vzt'ahoch, ktoré sa potom v podmienkach odcudzenej práce nestávajú potvrdením človeka, ale vystupujú voči nemu ako vonkajšia, cudzia sila.

Marx teda vykreslil štrukturovaný obraz odcudzenej práce upriamujúci pozornost' na prácu, ktorá popiera seba-potvrdenie človeka v produktívnej

\footnotetext{
8 Ide o citát zo slovenského prekladu z roku 1971. Výrazy „akt výroby“ a „,výrobná činnost““ sme nahradili výrazmi „akt produkcie“ a „produkujúca činnost”“, pretože súhlasíme s argumentmi M. Hausera, ktoré predostrel pri preklade časti Ekonomicko-filozofických rukopisov tvoriacich prílohu knihy E. Fromma (2004). Podla neho výraz „výroba“ nevystihuje dostatočne celú šírku významov pojmu „Produktion“, ktorý Marx používal a ktorý je odvodený z latinského „produco“ označujúceho tvorivú činnost' vo všeobecnosti (Hauser 2004: 150). Navyše, na rozdiel od výrazu „výroba“, výraz „produkcia“" umožňuje zhrnút' v jednom slove vytváranie materiálnych i nemateriálnych statkov.
} 
aktivite, odcudzuje výsledok takejto aktivity, ako aj jej spoločenský kontext. Otázkou je, akú podobu má práca, ktorej existencia bola deformovaná do podoby odcudzenej práce. Povedané inak, čo stojí „oproti“ odcudzenej práci popísanej uvedenými aspektmi? Ako chápat' prácu v jej neodcudzenej podobe?

Jeden typ odpovedí ponúka prúd tzv. humanistickej interpretácie, ktorá chápe odcudzenú prácu predovšetkým ako nástroj kritiky sociálnych a ekonomických podmienok v kapitalistickej ekonomike? ${ }^{9}$ Predpokladá, že odcudzená práca predstavuje deformáciou neodcudzenej l'udskej činnosti, ktorá je neuskutočneným potenciálom človeka. Erich Fromm, jeden z jej klúčových predstavitel'ov, chápal prácu $\mathrm{v}$ neodcudzenej podobe ako sebavyjadrenie človeka, realizáciu jeho tvorivých síl, hegelovský akt l'udského sebatvorenia (Fromm 2004: 33-34). Oproti odcudzenej práci kladie idealizovanú predstavu l'udskej činnosti, ktorá je vlastná človeku, jeho podstate, prirodzenosti. Odcudzenie teda znamená, že „l'udská existencia sa odcudzuje l'udskej podstate a človek nie je tým, čím v možnosti je, inak povedané, že nie je tým, čím by mal byt', a že by mal byt' tým, čím môže“. Vo svojej odcudzenej podobe „prestáva svojou povahou vyjadrovat' l'udské tvorivé sily“" (Fromm 2004: 37). Odcudzená práca je teda odcudzením sa podstate charakteristickej pre človeka ako druh.

Toto poňatie odcudzenej práce má silnú imaginatívnu stránku, ktorá posilňuje jeho kritické vyznenie. Odcudzenie a odcudzená práca tu vystupujú ako nehybnost', mŕtva predmetnost', strnulost'. Odcudzená práca je hriechom: slovo odcudzenie má podla Fromma podobný význam ako slovo hriech v teistickom jazyku - „opustenie samého seba, opustenie Boha v nás“ (2004: 25-37). A ako taká je potom znemožnením rozvíjania l’udského potenciálu, čo predstavuje jedno z hlavných zlyhaní kapitalizmu.

Na druhej strane, vytvorenie opozície „odcudzená práca - neodcudzená idealizovaná práca“ je konfrontované s argumentom, že Marx s takýmto rozlíšením nepracoval. A namiesto toho rozlišoval medzi druhovou činnostou človeka ako univerzálnou transhistorickou kategóriou, ktorá je ontologickou determináciou l’udskej existencie (Mészáros 1970), a jej historicky špecifickými formami. Práca v kapitalizme je len jednou zo špecifických foriem práce a odcudzená práca, ktorú Marx vzt’ahoval najmä $\mathrm{k}$ práci v kapitalizme ${ }^{10}$, teda predstavuje len jednu z podôb, ktoré l'udská aktivita nadobúda v rôznych historických podmienkach (Halas 2010). Jej protipólmi tak nie sú l'udská

\footnotetext{
9 Zároveň, Ekonomicko-filozofické rukopisy sú tu považované za zdroj etickej dimenzie Marxovho diela.

${ }^{10}$ V Marxových prácach možno nájst’ aj pasáže, ktoré rozširujú „záber“ odcudzenej práce aj mimo kapitalizmus. Tak napríklad v Rukopisoch „Grundrisse“ uvádza, že práca je vnímaná ako čisto inštrumentálna a neslobodná aktivita vo všetkých spoločnostiach charakteristických triednym rozdelením, nielen v kapitalizme (Sayers 2011: 88). Takýchto príkladov je však príliš málo a nemajú ucelenú podobu, ktorá by obstála v porovnaní so systematickým pojednaním odcudzenej práce $\mathrm{v}$ kapitalizme.
} 
kreativita, seba-potvrdenie alebo seba-rozvíjanie ako danosti l'udskej prirodzenosti.

Skutočnost', že Fromm - tak ako aj d’alší predstavitelia humanistického nazerania na Marxa - interpretujú odcudzenie odkazom na rozlíšenie l'udskej existencie a podstaty, otvorilo diskusiu o tom, či a ako Marx pracoval s ideou l'udskej podstaty a l'udskej prirodzenosti, a ako to súviselo s odcudzením a odcudzenou prácou. $\mathrm{V}$ tejto súvislosti možno rozlíšit' tri názorové tábory (Byron 2016). Podl'a Louisa Althussera a ním inšpirovaných marxistov neskorší Marx odmietal koncept univerzálnej l'udskej podstaty. Za dôležitý míl'nik sa považuje Šiesta téza o Feuerbachovi, v ktorej Marx uvádza, že „l'udská podstata nie je nejaké abstraktum vlastné jednotlivému indivíduu. Vo svojej skutočnosti je to súhrn spoločenských vzt'ahov." S dôrazom, ktorý kládol na historický vývoj a zmenu, nemohol predpokladat' existenciu univerzálnej, transhistorickej l'udskej podstaty. Treba dodat', že v prospech tézy, že Marx odmietol koncept l'udskej podstaty, sa vyslovovali aj d’alší autori, ktorí nezdiel'ali Althusserove názory. Napríklad Israel (1976) videl potvrdenie tohto posunu $\mathrm{v}$ tom, že Marx sa od teórie odcudzenia presunul $\mathrm{k}$ teórii reifikácie a fetišizmu komodít.

Druhým táborom sú zástancovia historického nazerania na l’udskú prirodzenost', podl'a ktorých l'udská prirodzenost' nie je nemenná a univerzálna, ale je to historický fenomén, ktorý sa mení v čase (Sayers 2011). Čo je dôležité, vo vývoji takto chápanej l’udskej prirodzenosti zohráva dôležitú úlohu odcudzená práca, pretože v sebe implicitne zahŕňa predpoklad, že odcudzenie môže byt' prekonané a práca sa môže stat' seba-napínajúcou aktivitou. Odcudzená práca ako popretie l'udskej prirodzenosti nepredstavuje len negatívny jav, ktorý je potrebné kritizovat', ale má aj pozitívnu úlohu: tým, že predstavuje nevyhnutný stupeň l’udských dejín, vytvára podmienky na svoje prekonanie (Sayers 2011: 83-85) ${ }^{11}$.

Tretiu skupinu tvoria autori argumentujúci, že Marx neodmietol ideu univerzálnej, transhistorickej l’udskej prirodzenosti (Geras 1983), prípadne, že túto ideu aktívne rozvíjal v celom svojom diele (Byron 2016; Wallimann 1981). Podobne ako v prípade historického pohl'adu na l'udskú prirodzenost', aj tu nájdeme dôraz na vzt'ah medzi l'udskou prirodzenost'ou a odcudzením: Marxov koncept odcudzenia by bol bez transhistorickej interpretácie l'udskej prirodzenosti oslabený, nakol'ko by nebolo možné stanovit', v čom odcudzenie vôbec spočíva. Podl'a Chrisa Byrona Marxov esencializmus predpokladal l'udskú prirodzenost' spočívajúcu v schopnostiach kreatívnej a komplexnej

\footnotetext{
11 Je zaujímavé, že Bell už na prelome 50. a 60. rokov tvrdil, že Marx zobral koncept, ktorý nemecká filozofia považovala za ontologický fakt, a dal mu sociálny obsah. A tento krok mal vel'ký dosah, pretože kým ontologický fakt musel človek len akceptovat', odcudzenie ako sociálny fakt, ukotvený v špecifickom systéme historických vzt'ahov, môže byt' prekonaný zmenou spoločenského systému. (Bell 1959: 939).
} 
činnosti, ktorej vyjadrenia/prejavy sa môžu menit' v rôznych spoločenských podmienkach. Spôsob, akým je prirodzenost' vyjadrená v konkrétnych spoločenských podmienkach, je súčast'ou celkovej podstaty človeka. „L'udská prirodzenost' je podmienkou širšej l'udskej podstaty...ak analyzujeme niekoho podstatu, musíme mat' na pamäti vyjadrenie ludskej prirodzenosti spolu so spoločensko-ekonomickými špecifikami daného historického momentu“ (Byron 2016: 392). Podobným smerom sa uberá aj Isidor Wallimann (1981), ktorý u Marxa rozoznáva dva modely l'udskej prirodzenosti: biologický model definujúci všeobecnú l’udskú prirodzenost' v opozícii voči živočíšnej ríši a historický model zdôrazňujúci také vlastnosti, ktoré variujú v čase i mieste. Spoločnou črtou týchto prístupov je, že zosúlad'ujú ideu univerzálnej l’udskej prirodzenosti s požiadavkou na historickú variabilitu, ktorá reflektuje meniacu sa podobu spoločenských vzt’ahov/spôsobov produkcie.

Vyššie uvedené interpretácie dávajú do pozornosti niektoré napätia Marxovho konceptu odcudzenia. Jeho priamočiara morálna kritika je konfrontovaná s poukazom na jeho pozitívnu historickú funkciu (odcudzenie ako nevyhnutné štádium svojho prekonania) alebo na jeho rolu ako príčiny súkromného vlastníctva v systéme kritiky politickej ekonómie. Kl'účová je aj diskusia ohl'adne ponímania l'udskej prirodzenosti a príklonu $\mathrm{k}$ esencializmu. To všetko sú témy, ktoré rezonovali $\mathrm{v}$ diskusiách dvadsiateho storočia a viedli $\mathrm{k}$ zásadným sporom o povahe konceptu odcudzenej práce.

Teoretické reflexie a empirický výskum odcudzenia a odcudzenej práce v 20. storočí: hlavné témy a názorové strety

Nové podoby industrializácie $\mathrm{v}$ dvadsiatom storočí a s nimi spojené premeny sveta práce vytvorili podmienky pre reflexiu Marxových téz i pre rozvíjanie samostatných, od Marxa oprostených iniciatív. Napriek tomu, že je t’ažké zosumarizovat' tento vývoj do podoby nejakej typológie, pokúsime sa $\mathrm{s}$ vedomím určitého zjednodušenia - o prehl'ad najdôležitejších typov argumentov.

Marxom inšpirovaná kritika odcudzenia sa stala jadrom prác Frankfurtskej školy. V centre pozornosti bola kritika inštrumentalizácie človeka ekonomickým systémom zameraným na rast a profit, jeho represívnych prejavov a absolutizovanej kontroly, ako aj schopnosti masovej produkcie zahmlievat' podstatu odcudzenia (Frayne 2016). Či už to bol Theodor Adorno, Max Horkheimer alebo Herbert Marcuse, v pozadí ich kritiky stálo presvedčenie o totalitárnych sklonoch kapitalizmu, ktoré vedú $\mathrm{k}$ potlačeniu potenciality človeka a k odcudzeniu. V knihe Jednorozmerný človek (1991) Marcuse presvedčivo popísal, ako sa človek stáva objektom cudzích síl a stráca schopnost' kreatívnej subjektivity. Poukázal na rozdiel medzi pravými a nepravými potrebami, pričom tie druhé pripísal tlaku spoločenských síl, ktoré majú záujem

Sociológia 52, 2020, č. 5 
o potlačenie indivídua a stávajú sa nástrojom ovládania a sociálnej kontroly udržiavania odcudzenia (1991: 36). Odcudzenie sa stalo dôležitou témou predovšetkým pre Fromma, ako sme ukázali v predchádzajúcej časti. A nešlo len o interpretáciu Marxových spisov, ale aj o aktívne rozvíjanie vlastných teórií, a to najmä pri konceptualizácii rozdielov medzi negatívnou a pozitívnou slobodou (Jay 1973: 99). Odcudzená práca ako taká však nebola objektom špecifického skúmania hlavných predstavitel'ov prvej generácie Frankfurtskej školy. Túto oblast' prebrali iní marxistickí autori.

Marxove tézy do sociologických empirických výskumov práce preniesol ako jeden z prvých Robert Blauner (1964). Vychádzajúc z predpokladu, že inherentnou súčast'ou modernej priemyselnej výroby a jej byrokratickej organizácie je odcudzenie (1964: 167), kládol si otázku, či a ako odcudzenie variuje v rôznych kontextoch výroby. Zameral sa na štyri faktory, ktoré odlišovali rôzne priemyselné odvetvia a mohli tak vplývat' na rôznu úroveň odcudzenia. Kým typ použivanej technológie bol kl’účovým determinantom odcudzenia, del'bu práce, sociálnu organizáciu výroby a jej ekonomické štruktúry považoval za intervenujúce premenné. Odcudzenie - ktoré vzt'ahoval $\mathrm{k}$ odcudzenej práci - operacionalizoval do štyroch dimenzií, ktoré mali podl'a neho jasné prepojenie na pôvodné Marxove dimenzie ${ }^{12}$. Šlo o bezmocnost' chápanú ako stratu slobody a kontroly v práci, absenciu významu a ciel’a práce, sociálnu izoláciu v zmysle absencie identifikácie $\mathrm{s}$ organizáciou a sebaodcudzenie ako absenciu pocitu naplnenia v pracovnej činnosti.

Blauner vo svojom výskume - založenom na analýze dát $\mathrm{z}$ dotazníkov a rozhovorov - dospel $\mathrm{k}$ záveru, že úroveň odcudzenia skutočne variuje $\mathrm{v}$ rôznych priemyselných odvetviach, pričom $\mathrm{v}$ odvetviach $\mathrm{s}$ menej rozvinutou technológiou identifikoval vyššiu úroveň odcudzenia a naopak. Zároveň predpokladal, že $\mathrm{s}$ vývojom technológie nedochádza $\mathrm{k}$ nárastu odcudzenej práce: priebeh vzt’ahu medzi rozvojom technológií a odcudzením popísal ako obrátené U. Tieto zistenia sa stali spúšt’ačom výskumov o vplyve technológie na odcudzenú prácu (pre prehl'ad pozri Shepard 1977), a to napriek silnej metodologickej kritike, ktorá Blaunerov výskum sprevádzala. Kritika sa väčšinou týkala použitých dát, spôsobu analýzy i formulácie záverov (Edgell 2012). Avšak objavili sa aj výhrady, že ide o psychologizáciu problému, a teda o sociológiu bez spoločnosti (Shepard 1977), čomu napomohla už spomenutá inšpirácia sociálno-psychologickými výskumami.

Pevnejší otlačok Marxa do svojej práce vtlačil Harry Braverman (1974), ktorý preformátoval sociologický pohl'ad na prácu a pracovisko a urobil z nich arénu triednych konfliktov. Zmeny, ktoré sa udiali vo vztahu medzi

\footnotetext{
12 Treba však poznamenat', že tieto štyri dimenzie nevyplynuli len z inšpirácie Marxom, ale že Blauner ich vybral na základe skoršej štúdie Malvina Seemana (1959), ktorá zásadne ovplyvnila nemarxistický prúd empirického skúmania odcudzenia.
} 
zamestnancami a manažmentom v dvadsiatom storočí, vnímal ako výsledok triedne podmienenej snahy o kontrolu a moc nad pracovným procesom a nie ako dôsledok triedne neutrálnych princípov zvyšovania efektívnosti a zavádzania nových technológií (Smith 1994). Kontrola pracovného procesu zaistila, aby sa $\mathrm{z}$ formálneho vlastníctva práce stalo reálne, a tak prispela $\mathrm{k}$ dynamike kapitalizmu založenej na akumulácii kapitálu. V tejto súvislosti Braverman vyzdvihol úlohu troch princípov taylorizmu: zhromažd’ovanie poznatkov o výrobnom procese, odobratie týchto poznatkov z rúk zamestnancov a ich koncentrácia do rúk manažmentu, a nakoniec využitie tohto monopolu na kontrolu pracovného procesu (1974: 119). Výsledkom bolo znižovanie náročnosti práce a v konečnom dôsledku jej degredácia. Preberanie kontroly nad pracovným procesom a degradácia obsahu práce bola pre Bravermana potvrdením pretrvávajúceho odcudzenia. Práca sa stala odcudzenou v zmysle „scudzenia“" jej obsahu zamestnancom. Bravermanova kniha vyvolala obrovský ohlas ${ }^{13}$ a ovplyvnila smerovanie sociológie práce presunutím pozornosti na dynamiku kontroly pracovného procesu, vytváranie súhlasu či rezistenciu na pracovisku.

Popri Marxom inšpirovaných prístupoch sa jedným z najvýraznejších a najrozšírenejších prúdov $\mathrm{v}$ rámci sociológie stal tzv. sociálno-psychologický výskum. Na dlhé obdobie ovplyvnil spôsob, akým sa uvažovalo o odcudzení a odcudzenej práci a ako sa s ňou empiricky pracovalo. Malvin Seeman (1959, 1972, 1975), klúčová postava tohto prístupu, sa síce primárne zaoberal odcudzením ako takým, jeho štúdie však udali tón aj empirickému skúmaniu odcudzenej práce. Odcudzenie chápal ako psychologický stav jednotlivca a nie ako atribút sociálneho systému. Snažil sa z neho urobit' predmet kvantitatívneho empirického výskumu založeného na nemarxistickej operacionalizácii, s ciel'om identifikovat' podmienky, ktoré generujú rôzne varianty odcudzenia alebo ich behaviorálne konzekvencie (Seeman 1959: 784).

Seeman rozoznával najprv pät' a neskôr šest' variantov odcudzenia, ktoré napojil na dôležité sociologické koncepty: bezmocnost', beznormovost' (anómia), sociálna izolácia, bezvýznamovost', odcudzenie od kultúry (hodnotová izolácia), či seba-odcudzenie. Rôznorodost' teoretických východísk jednotlivých variantov mu nebránila definovat' ich jednotiacim spôsobom, a síce pomocou konceptov „očakávaní“ a „hodnoty posilnenia“ prepožičaných z teórie sociálneho učenia J. J. Rottera ${ }^{14}$. Bezmocnost' tak definoval ako nízke očakávanie jednotlivca, že jeho správanie dokáže ovplyvnit' výskyt výsledkov alebo hodnôt posilnenia, o ktoré sa snaží (Seeman 1959; 1975). Beznormovost' zase vymedzil ako vysoké očakávania, že na dosiahnutie želaných výsledkov je

\footnotetext{
13 Pre prehl'ad kritiky i obhajoby vid’ napríklad Littler, Salaman 1982; Smith 1994.

14 Očakávania vyjadrujú subjektívnu pravdepodobnost', že dané správanie povedie k určitému výsledku, odmene. Hodnota posilnenia odkazuje k želanému výsledku správania. Potenciálne správanie je potom funkciou očakávaní a hodnoty posilnenia.
} 
nevyhnutné použit' spoločensky neschval'ované prostriedky. Odcudzenú prácu Seeman zachytil variantom nazvaným „seba-odcudzenie“, ktorý definuje ako stratu vnútorného zmyslu vykonávanej aktivity. Seba-odcudzenie sa teda vyskytuje tam, kde vykonávaná aktivita sama osebe nie je zdrojom hodnoty, odmeny. V jazyku očakávaní ide o stupeň závislosti aktivity (správania) na budúcich odmenách, ktoré sa nachádzajú mimo samotnej aktivity (Seeman 1959: 790). Zaradenie takto chápaného seba-odcudzenia medzi varianty odcudzenia Seeman zdôvodňuje odkazom na klasické opisy odcudzenej práce (aj u Marxa a Fromma), ktorá - rovnako ako Seemanov koncept - spočíva vo výkone nenapĺńajúcej a nekreatívnej činnosti (Seeman 1972: 473).

Ideu seba-odcudzenia ako odcudzenej práce rozvíjal Seeman aj empiricky, pričom sa však už zbavil „zát’aži““ súvisiacich s Marxom (Seeman 1967). Empirická analýza mala podobu kvantitatívneho výskumu zameraného na konzekvencie odcudzenej práce, ktorá bola operacionalizovaná prostredníctvom skúseností s prácou. Redukcia odcudzenej práce na empiricky meratel'né psychologické stavy jednotlivca a rezignácia na skúmanie objektívnych podmienok, ktoré sa stali rozšŕreným módom v rámci sociálno-psychologického prístupu, vyvolalo silnú kritiku (Kon 1967).

Táto kritika prichádzala od množstva marxisticky orientovaných autorov. Ohlas získali argumenty Hortona (1964), ktorý poukázal na vyprázdnenost' konceptu, na transformáciu pôvodne radikálnej idey na konformistický koncept pod pláštikom objektívnej, hodnôt zbavenej vedy. Koncept odcudzenia podl'a neho pôvodne predstavoval metaforu pre radikálny útok na dominantné inštitúcie a hodnoty priemyselnej spoločnosti (1964: 283) $)^{15}$. Bol nástrojom kritiky ekonomického individualizmu a jeho racionalizácie v podobe ekonomického a politického liberalizmu - doktrín strednej triedy, ktoré sa opierali o atomistickú interpretáciu spoločnosti. Horton argumentoval, že zdrojom radikálnosti konceptu bolo aj jeho sociologické ukotvenie, vyjadrené $\mathrm{v}$ kolektivistickej definícii človeka stojacej $\mathrm{v}$ protiklade $\mathrm{k}$ ahistorickému a individualistickému obrazu človeka žijúceho v spoločnosti tvorenej zhlukom kontraktuálnych vzt’ahov. To všetko sa v skúmaní odcudzenia ako série psychologických stavov strácalo. Iróniou je, že z konceptu odcudzenia ako nástroja kritiky ekonomicko-politických ideológií strednej triedy sa stal technokratický nástroj využívaný práve jej príslušníkmi.

V podobnom duchu argumentoval aj Schweitzer (1996), ktorý hodnotil sociálno-psychologický prístup ku skúmaniu odcudzenia a odcudzenej práce $\mathrm{z}$ väčšieho časového odstupu. Zameranie na neutrálne deskriptívne charakteristiky odkazujúce $\mathrm{k}$ individuálnym pocitom, postojom alebo vnímaniu podl'a neho redukovalo pôvodne obsiahly Marxov koncept a oddelilo ho od jeho

15 Okrem odcudzenia Horton kritizoval aj vtedajší spôsob narábania s konceptom anómie. 
intelektuálnych koreňov v normatívnej teórii. Podobne ako Horton, aj Schweitzer rozvíja dva typy argumentov. Prvý je kritikou sociologického obsahu, druhý smeruje o stupeň vyššie - k sociológii poznania. Schweitzer tvrdil, že sociálno-psychologická tradícia empirických výskumov má vel'mi obmedzené možnosti pochopit' makrosociologické premenné súvisiace sodcudzením, nevie ho ukotvit' $\mathrm{v}$ širších súvislostiach, kde by spoločenské štruktúry a procesy boli prepojené so subjektívnymi formami odcudzenia (1996: 24). Po druhé, zbavovanie sa ,ideológie“ spojenej s Marxovým chápaním odcudzenia, legitimizované požiadavkami na vedeckú objektivitu a hodnotovú neutralitu, je samo osebe normatívnou procedúrou, pretláčaním špecifického pohl'adu na svet vlastného určitým sociálnym triedam.

Platí to aj pre skúmanie odcudzenej práce, kde však Schweitzer poukázal na d’alšiu dôležitú konotáciu - na to, ako sériová výroba kvantitatívnych údajov o odcudzenej práci, zbavená naliehavosti a kritiky, poslúžila na legitimizáciu manažérskych stratégii zameraných na ovplyvňovanie adaptácie zamestnancov na nevyhovujúce pracovné podmienky. Ked’že problém odcudzenej práce je realokovaný na úroveň jednotlivca, riešenia taktiež začínajú tam (1996: 28). Klúčovou otázkou sa tak stáva individuálna adaptácia na dominantné hodnoty a inštitúcie v spoločnosti, zatial čo potreba transformácie spoločenských vzt’ahov sa upozad’uje. Problémom nie je práca a jej podmienky, ale reakcie na n̆u.

Od 70tych rokov dvadsiateho storočia sa objavilo množstvo d'alších sociologických prístupov, ktoré sa síce primárne netýkali odcudzenej práce ako takej, ale postihovali niektoré jej dôležité konštitutívne aspekty. Michael Burawoy (1979) v nadväznosti na Bravermana (a čiastočne aj v opozícii voči nemu) poukázal na fakt, že organizácia práce nie je len predmetom kontroly zo strany vyšších spoločenských tried, ale aj komplexnejších stratégií vrátane techník vytvárania súhlasu a profylaktiky rezistencie. Andre Gorz (1989) zdôrazňoval kontrolnú a disciplinujúcu úlohu platenej práce, ktorá je nástrojom socializácie, normalizácie a štandardizácie. Každá práca má podl’a neho tri dimenzie - organizáciu pracovného procesu, vzt’ah k produktu práce a obsah práce. Odstránenie odcudzenia ako takého, ktoré vnímal predovšetkým ako absenciu autonómie a možnosti vyjadrenia kreatívneho potenciálu, je možné len vtedy, ak prebehne na každej z týchto dimenzií (1989: 78). Inšpirovaný tézou Marcusa, že ekonomická sloboda znamená oslobodenie od ekonomiky, Gorz argumentoval v prospech „konca práce“ respektíve „post-pracovnej spoločnosti“ (Granter 2009). Špecifický aspekt odcudzenej práce popísal Arlie Hochschild (1983) pomocou konceptu „emocionálna práca“. Emocionálna práca, typická pre sektor služieb, je založená na manažmente emócií. Pocity, zvyčajne autentické prejavy človeka, sa stávajú pracovným nástrojom, zapínaným a vypínaným na základe externých kritérií, a ako také sú základom 
komodifikovatel'nosti pracovnej sily. Výsledkom je emocionálna disonancia (1983: 90), ktorá vedie k odcudzeniu.

Popri vyššie uvedených prístupoch, ktoré vtlačili určitú pečat' skúmaniu práce a jej odcudzených podôb, vzniklo množstvo d'alších štúdií, ktoré na odcudzenú prácu nahliadali z partikulárnych perspektív, často kopírujúcich hranice sektorov ekonomiky alebo povolaní. Avšak všeobecnejšie platí, že odcudzená práca sa dostala mimo hlavný záujem sociológie, slúžiac ako parciálny indikátor stavu sveta práce. To prispelo - spolu s pocitom, že vlna záujmu prevetrala každé jej zákutie - k oslabeniu teoretických iniciatív v danej oblasti. V súčasnosti chýba systematickejšia snaha o teoretické rozvíjanie konceptu odcudzenej práce, a to najmä tých jeho aspektov, ktoré by umožnili kriticky nanovo nasvietit' existujúce i novovznikajúce charakteristiky a formy práce, ktoré sú brané ako samozrejmost' či dokonca nevyhnutnost'. V d’alšej časti preto ukážeme, kde vidíme inšpirácie pre sociologické rozvíjanie konceptu odcudzenej práce a ako sa vzt’ahujú k dôležitým otázkam, ktoré $\mathrm{v}$ súvislosti s odcudzenou prácou doteraz vyvstali.

\section{Možnosti revitalizácie konceptu odcudzenej práce}

Silný potenciál pre rozvíjanie konceptu odcudzenej práce vidíme v kritickej teórii spoločnosti. Kritická teória sa už od svojich počiatkov zaoberala úvahami o odcudzení a jeho podobách $\mathrm{v}$ modernej spoločnosti, pričom v centre pozornosti bola aj práca a blokovanie jej emancipujúceho potenciálu. Vyplývalo to z dôrazu, ktorý kládla na odhal'ovanie kontradikcií, nespravodlivosti a sociálnych patológií. Kritériami diagnostiky pritom nie sú apriórne hodnoty alebo idey aplikované na existujúce podmienky, ale rekonštruované prísl'uby a zvnútornené ideály spoločnosti a z nich vyplývajúce sociálne napätia (Honneth 2011; Thompson 2017). Na tomto základe sa v kritickej teórii vykryštalizovali prístupy, ktoré sa síce nie vždy priamo vzt’ahujú k odcudzenej práci, ale ponúkajú inšpiratívne argumenty, ktoré možno použit' pri rozvíjaní konceptu odcudzenej práce. $\mathrm{Na}$ nasledujúcich riadkoch budeme venovat' pozornost' Axelovi Honnethovi, poprednému predstavitel'ovi špecifického prúdu kritickej teórie, ktorý dlhodobo kritizuje spoločenské vedy kvôli ignorovaniu toho, čo sa deje vo svete práce, a ktorý prácu explicitne zahrnul do svojho modelu uznania.

Honnethova analýza povahy práce prešla vývojom od explicitného záujmu o odcudzenú prácu až po včlenenie kritiky súčasných podôb práce do teórie uznania. Začiatkom 80 tych rokov sa pokúsil o oživenie kritického konceptu práce na základe rekonštrukcie Marxovej teórie odcudzenia. Vychádzal pritom $\mathrm{z}$ predpokladu, že koncept práce $\mathrm{v}$ spoločenských vedách postupne strácal svoj kritický náboj. Prejavilo sa to aj v ústupe Marxovho poňatia odcudzenej práce $\mathrm{z}$ teoretického jazyka marxisticky orientovaných autorov či $\mathrm{v}$ neutralizácii konceptu práce v sociológii pod vplyvom taylorizmu. V štúdii „Work and 
instrumental action: on normative basis of critical theory“ (1982) poukázal na niektoré konceptuálne nejasnosti Marxovho poňatia práce. Odkazujúc na zmeny v obsahu jeho konceptu práce hl'adal odpoved' na otázku, na akom základe možno zosúladit' ideu, že odcudzenie je ukotvené v pracovnom procese, s ideou, že emancipácia človeka sa odohrá práve prostredníctvom práce. Teda, ako vôbec chápat' prácu, ktorá umožňuje transformáciu z odcudzenia na emancipáciu, respektíve ako vystužit medzeru medzi antropologicky určeným charakterom práce a historickou situáciou odcudzenej práce (Deranty 2009: 46).

Jadrom rekonštrukcie však bola kritika chápania práce u vybraných autorov (Max Scheler, Hannah Arendt) a predovšetkým kritika Jurgena Habermasa a jeho dištinkcie medzi komunikatívnym a inštrumentálnym konaním ${ }^{16}$. Habermas totiž prácu „odsunul“ do oblasti inštrumentálneho konania, v ktorej sa uplatňuje logika efektívnosti a produktivity, čím sa redukovala bohatost' Marxovho konceptu práce a eliminovali sa jeho normatívne obsahy. Inštrumentálne konanie u Habermasa zahŕňalo akýkol'vek akt pretvárania, osvojovania si objektu. Znamená to, že nerozlišoval medzi prácou ako inštrumentálnym konaním, pri ktorom subjekt sám štrukturuje a kontroluje svoje aktivity - na základe vlastnej iniciatívy a poznatkov, a prácou ako inštrumentálnym aktom, ktorý tieto charakteristiky nemá (Honneth 1982: 180). Podl'a Honnetha, kritický koncept práce takéto rozlíšenie musí umožňovat'. Vzt'ahovanie sa k objektu práce sa môže stat' formatívnym procesom, v ktorom sa z človeka stáva uvedomelý, autonómny l'udský subjekt (Boston 2018: 5). Ruka v ruke s tým potom ide možnost' identifikovat' praktické a morálne poznanie, ktoré nepochádza z oblasti komunikatívneho konania (ani z oblasti úzko chápaného inštrumentálneho konania), ale je výsledkom skúseností a procesov v oblasti práce - konkrétne skúseností s deštrukciou skutočných aktov práce, ktorú prináša racionalizácia a taylorizmom vyvolané zmeny $\mathrm{v}$ organizácii práce (Honneth 1982: 181). Honneth teda Habermasovi vyčíta redukciu konceptu práce, nedostatočné rozlišovanie tých jeho dimenzií, ktoré ho robia nástrojom kritickej analýzy, a v konečnom dôsledku absenciu normatívnej signifikancie práce. Ako konštatuje na záver, Habermasove základné koncepty vyzerajú tak, ako keby proces oslobodenia sa od odcudzenej práce, o ktorom písal Marx, už bol ukončený (1982: 182).

Projekt rekonštrukcie kritického konceptu práce opierajúci sa o Marxovo chápanie odcudzenia však neskôr Honneth opúšt’a a úvahy o povahe práce rozvíja v rámci teórii uznania (Honneth, 2010). Počut' tu však aj ozveny textu z roku 1982: intersubjektívny prístup teórie uznania znamená odklon od inštrumentálneho vzt’ahu subjektu k svetu a umožňuje formulovat' tak kritiku

${ }^{16}$ Honneth sa pri analýze opieral o Habermasov text „Poznanie a l’udské záujmy“ vydaný v roku 1968. 
prevládajúceho zneuznania ako aj pozitívne predpoklady sebarealizácie človeka (Hrubec a kol. 2012: 18). Honneth teda nad’alej rozvíja nielen kritiku, ale aj vysvetl'ujúcu normativitu (Hrubec 2011) ${ }^{17}$. Normatívnu signifikanciu práce však už nehl'adá v samotnej povahe práce, ale v inštitucionálnom rámci, v ktorom je ukotvená. Je to práve tento rámec tvorený vzt’ahmi založenými na trhových výmenách, ktorý zjednocuje množstvo rôznych typov práce, ktoré v súčasnosti vykazujú tak vel'kú variabilitu, že nezdiel'ajú takmer žiadnu spoločnú vlastnost', ktorá by mohla byt' základom normatívnych očakávaní (Boston 2018).

Honnethov prístup je založený na imanentnej, internej kritike, ktorá predpokladá, že je možné nájst' štandard, ktorý predstavuje legitímnu, racionálnu požiadavku nachádzajúcu sa v rámci samotných kritizovaných vzt’ahov (2010: 229). Kritika práce tak nie je založená na externých kritériách, nech už majú akúkol'vek povahu. Naopak, mali by byt' inherentnou súčast'ou spoločnosti a trhu, v rámci ktorých je práca realizovaná. Otázkou ale je, kde hladat’ takéto štandardy? V ekonomickej sociológii nájdeme teórie, ktoré poukazujú na to, že trh práce závisí od normatívnych predpokladov a že nič také ako „samoregulujúci“" trh neexistuje (Beckert 2002). Príkladom je aj Émile Durkheim, ktorého úvahy o ne-ekonomických, morálnych predpokladoch trhových výmen si všíma aj Honneth. Inšpiruje sa jeho argumentom, že ekonomický systém má mat' aj integrujúcu úlohu, pričom jej úspech závisí od naplnenia určitých morálnych predpokladov (ako sú sociálna spravodlivost' či možnost' vykonávat' zmysluplnú prácu). Honneth zdôrazňuje, že tieto predpoklady nie sú „priložené" na trh práce zvonku, ale predstavujú funkčne nevyhnutné podmienky spoločenskej integrácie $\mathrm{v}$ rámci daného ekonomického systému.

Pôvodne Honneth hladal takéto interné kritériá na základe predpokladu, že všetky formy práce by mali vykazovat' tendenciu k organickému holizmu, autonómnej kontrole nad pracovným procesom a cielenosti - charakteristikám odvodeným od ideálu práce remeselníka $\mathrm{v} 19$. storoč ${ }^{18}{ }^{18}$ V tomto duchu sa snažil identifikovat' normatívne očakávania pracovníkov, a to napríklad na základe prejavov rezistencie na pracovisku a požiadaviek na autonómiu. Tento pokus však nakoniec zamietol, pretože takýmto kritériám chýbal prvok preukázatel'ného univerzalizmu: rozmanitost' pracovných aktivít prakticky znemožňuje predpokladat', že si vyžadujú, aby boli štrukturované a vykonávané podobným spôsobom. Preto sa Honneth obrátil k takým očakávaniam, ktoré sa týkajú inštitucionálnych rámcov práce (trhov práce).

\footnotetext{
${ }^{17}$ Hrubec (2011) ponúka prenikavú analýzu vzt’ahov medzi troma formami výkladu v kritickej teórii - kritikou, vysvetlením a normativitou, pričom pozornost' venuje aj Honnethovi a jeho výkladovým schémam.

18 Ideál remeselnej práce (spolu s ideálom umeleckej práce) v jeho romantizovanej podobe - ako model autonómnej, zmysluplnej práce, v ktorej je človek v kontakte so svojím produktom i okolím - slúžil v 19. ale i 20. storočí aj ako štandard externej kritiky. Nemal však praktický dopad na povahu zápasov robotníckeho hnutia, pretože sa podla Honnetha mín̆al $\mathrm{s}$ jeho požiadavkami a predstavami (2010: 225-226).
} 
Honneth konštatuje, že kapitalistické trhy (práce) nie sú len prostriedkom na zvyšovanie ekonomickej efektívnosti, ale aj nástrojom sociálnej integrácie (2010: 236) ${ }^{19}$. A v takomto prípade je podl'a neho zrejmé, že závisia od splnenia morálnych prísl’ubov, ktoré sprevádzali ich vznik a expanziu. Zároveň, ich fungovanie sa odvíja aj od legitimity danej vzájomným uznaním jednotlivcov a ich práce pre spoločnost'. Trhy nelevitujú vo vzduchoprázdne, ale sú normatívne ukotvené. Týmto argumentačným oblúkom si Honneth pripravil pôdu na to, aby (opät') obnovil kritický koncept práce. Tentokrát opretý o internú kritiku, ktorá nasvecuje realitu jej vlastnými prísl’ubmi internalizovanými v procese socializácie. Normy, ktorých porušovanie l’udia zakúšajú v oblasti práce, sa vzt’ahujú k vzájomnému sociálnemu uznaniu. Práca je teda jednou zo sfér uznania, pričom ide o uznanie toho, ako daný subjekt prispieva svojou prácou spoločnosti.

Honnethov projekt oživenia kritického konceptu práce poskytuje niekol'ko dôležitých impulzov pre sociologické premýšlanie o odcudzenej práci. Ponúka celkom úspešný návod, ako sa vyhnút' t’ažkostiam spojeným s esencializmom. $\mathrm{Na}$ rozdiel od prístupov opierajúcich sa o idealizované obrazy l'udskej prirodzenosti, práce alebo „dobrého života“, formulované najčastejšie expertmi, Honneth presúva pozornost' k zvnútorneným očakávaniam ohl'adne charakteristík inštitucionálnych rámcov a organizácie práce, ktoré môžu slúžit' ako štandardy kritiky. Tento postup možno aplikovat’ aj na odcudzenú prácu. Namiesto diskusie o skutočnej povahe človeka či o podstate dobrého života, ktorým sa človek prácou odcudzuje, odcudzená práca môže byt' tematizovaná vo vzt'ahu k všeobecne zdiel'aným predstavám, normám, čo by mala prinášat' a čo by mala znamenat' - berúc do úvahy integrujúce pôsobenie trhu. Získava sa tak pevnejší sociologický základ pre uvažovanie o odcudzenej práci. Zároveň to umožňuje nahliadnut' na odcudzenú prácu $\mathrm{z}$ dynamickejšej perspektívy. Normatívne ukotvenie trhov práce totiž nie je statické: normy sprevádzajúce organizáciu práce a jej výkon sa môžu menit'. Ak by sa tak aj nedialo vo významnej miere v minulosti, možno očakávat', že s technologickými a environmentálnymi zmenami k tomu dôjde v blízkej budúcnosti. Čo koncept odcudzenej práce založený na internej kritike môže zohl'adnit'. Pre sociológiu je dôležité, že dynamický model normatívneho ukotvenia umožňuje uvažovat' o odcudzenej práci aj $\mathrm{v}$ súvislosti s prebiehajúcimi sociálnymi konfliktami v spoločnosti, ktoré ovplyvňujú vnímanie ne-ekonomických predpokladov ekonomických vzt'ahov.

Interná kritika práce je pre uvažovanie o odcudzenej práci inšpiratívna aj tým, že v podstate prepája makro-spoločenskú úroveň (spoločenské normy a ich internalizácia) s úrovňou jednotlivcov (deklarácia normatívnych očaká-

19 Honneth upozorňuje, že len v tomto prípade možno hovorit' o morálnych predpokladoch trhu. Ak tento predpoklad neprijmeme, tak všetky ne-ekonomické podmienky trhu majú skôr povahu inštitucionálnych konvencií. 
vaní a požiadaviek). Odcudzená práca tak prestáva byt' čisto subjektívnym fenoménom skrytým v mysliach l’udí alebo objektívnou skutočnost’ou vyplývajúcou len z povahy vlastníckych vzt'ahov či technológie. Stáva sa výsledkom kombinácie mikro- a makro-spoločenských faktorov.

Nakoniec, z hl'adiska východísk tejto štúdie je prínosom aj dôraz na to, že kritický koncept práce musí umožňovat' nielen kritiku, ale aj emancipáciu. V tomto ohl'ade Honneth pokračuje v duchu Marxovho konceptu, odmietajúc inštrumentálno-ekonomické vnímanie práce.

Možno paradoxne, niektoré silné stránky prístupu Honnetha sú zároveň aj jeho slabými miestami. Možno rozlíšit prinajmenšom tri prúdy kritiky (Boston 2018: 3-4). Po prvé, predpoklad, že fungovanie trhov závisí od (skutočnej alebo domnelej) legitimity, ignoruje vzt'ahy moci a dominancie, ktoré môžu zaistit' inštitucionálnu reprodukciu aj bez nej. Po druhé, teoretizovat' ocenenie toho, ako l'udia svojou prácou prispievajú k fungovaniu spoločnosti, môže znamenat', že sa pripúšsta motivácia maximalizácie vlastného úžitku, a to aj na úkor ostatných. Tretí druh kritiky je z hl'adiska konceptu odcudzenej práce najdôležitejší. Tým, že Honneth v teórii uznania presunul pozornost' na inštitucionálny rámec práce, povahu samotnej práce akoby odsunul (na rozdiel od starších prác) nabok. Uzatvoril si tak cestu k deskripcii a následnej kritike jej obsahov.

Napriek týmto výhradám možno Honnethov prístup považovat' za jeden zo zdrojov revitalizácie konceptu odcudzenej práce. Inšpiratívnym spôsobom obnovuje kritickú analýzu práce, odmieta jej inštrumentálne chápanie, ako aj ideu normatívne neukotvených trhov. Perspektíva internej kritiky obracia pozornost' na diskrepanciu medzi normatívnym ukotvením a prejavmi nespravodlivosti alebo patológii vo svete práce. To všetko otvára nové možnosti pre uvažovanie o odcudzenej práci a zároveň vracia tejto téme aj naliehavost', ktorá sa zo sociologických analýz v posledných dekádach vytratila.

\section{Záver}

Práca je fundamentálna l'udská aktivita, prostredníctvom ktorej si človek vytvára vzt'ah $\mathrm{k}$ svetu, iným l'ud'om a prostredníctvom ktorej môže menit' i sám seba. Kritické teórie práce umožňujú, aby táto na prvý pohl'ad banálna skutočnost' nezostala skrytá pod nánosom pragmatických, technokratických otázok zameraných na zvyšovanie produktivity či organizačnej efektívnosti. Na ich základe možno rozvíjat' pokusy o revitalizáciu konceptu odcudzenej práce, ktorá by mohla napomôct' sociológii pochopit', ako sa z práce stáva cudzí element v našich životných projektoch. Dôležitým východiskovým bodom je argument, že trhy potrebujú legitimitu a ich ciel'om nie je len ekonomická efektívnost', ale aj sociálna integrácia. Dôraz na charakteristiky inštitucionálneho rámca sveta práce a od nich sa odvíjajúcu diskrepanciu medzi očakávaniami a skúsenost’ami so zneuznaním, nespravodlivost'ou či patológiou otvára 
nové možnosti pre konceptualizáciu odcudzenej práce. Rovnako aj pre empirický výskum, ktorému takáto perspektíva môže poskytnút' silný teoretický rámec. S jeho pomocou sa dajú potom hladat' odpovede na otázky, či a ako sa existujúca rôznorodost' zamestnaní a skúseností s prácou prejavuje v odlišnej miere či povahe odcudzenia od práce. Netreba však pritom zabúdat' na to, že koncept odcudzenej práce by mal pokrývat' aj otázku samotného obsahu a ciel'a práce.

Zároveň je potrebné mat' na pamäti, aby sa odcudzená práca nestala čisto subjektívnym fenoménom, redukovaným na osobnú skúsenost', respektíve jej intersubjektívne zdiel'anie. Odcudzená práca je aj produktom objektívnych podmienok, sociálnych štruktúr, ktorých poznanie sa nevyčerpáva len analýzou normatívnych štruktúr trhov práce. V tomto duchu možno rozvíjat' inšpiratívne momenty Honnethovej teórie ruka v ruke s poznatkami sociológie práce, ktorá sa orientuje na analýzu vplyvu podmienok práce a ich makro-spoločenského utvárania.

Daniel Gerbery pôsobí na Katedre sociológie FiF UK, kde prednáša ekonomickú sociológiu, sociologické metódy a štatistiku. Venuje sa otázkam nerovností, chudoby, sociologickým analýzam ekonomických javov a analýzam verejných politik.

\section{LITERATÚRA}

ALTHUSSER, L., 2005: For Marx. London: Verso.

BECKERT, J., 2002: Beyond the Market: The Social Foundations of Market Efficiency. Princeton: Princeton University Press.

BELL, D., 1959: The „Rediscovery“ of Alienation. The Journal of Philosophy, Vol. 56, No. 24, s. 933-952. https://doi.org/10.5840/jphil195956244

BLAUNER, R., 1964: Alienation and Freedom. Chicago: Chicago University Press.

BOSTON, T., 2018: New Directions for Critical Theory of Work: Reading Honneth Through Deranty. Critical Horizons. A Journal of Philosophy and Social Theory, s. 1-15. https://doi.org/10.1080/14409917.2018.1453287

BRAVERMAN, H., 1974: Labour and Monopoly Capital. New York: Monthly Review Press.

BURAWOY, M., 1979: Manufacturing Consent. Changes in the Labour Process under Monopoly Capitalism. Chicago: Chicago University Press.

BYRON, Ch., 2016: Essence and Alienation: Marx's Theory of Human Nature. Science and Society, Vol. 80, No. 3, s. 375-394. https://doi.org/10.1521/siso.2016.80.3.375

CLARK, S., 1991: Marx, Marginalism, and Modern Sociology. From Adam Smith to Max Weber. London: Palgrave Macmillan.

DERANTY, J. P., 2009: Beyond Communication. A Critical Study of Axel Honneth's Social Philosophy. Leiden: Brill.

EDGELL, S., 2012: The Sociology of Work. $2^{\text {nd }}$ Edition. London: SAGE. 
ERIKSON, K., 1986: On Work and Alienation. American Sociological Review, Vol. 51, No. 1, s. 1-8. https://doi/10.2307/2095474

FRAYNE, D., 2016: Critiques of Work. In: Edgell, S. et al. (eds.): The SAGE Handbook of Sociology of Work and Employment. London: SAGE, p. 616-633.

FROMM, E., 2004: Obraz člověka u Marxe. Brno: Nakladatelství L. Marek.

GERAS, N., 1983: Marx and Human Nature. Refutation of a Legend. London: Verso.

GORZ, A., 1989: Critique of Economic Reason. London: Verso.

GRANTER, E., 2009: Critical Social Theory and the End of Work. Farnham: Ashgate.

HALAS, J., 2010: Od filozofie práva k politickej ekonómii: Marxovo myslenie v rokoch 1842 - 1844. Filozofia, roč. 65, č. 5, s. 428-439.

HAUSER, M., 2004: Ediční poznámka. In: Fromm, E.: Obraz člověka u Marxe. Brno: Nakladatelství L. Marek.

HOCHSCHILD, A. R., 1983: The Managed Heart. Commercialization of Human Feelings. Berkley: University of California Press.

HONNETH, A., 1982: Work and instrumental action: on the normative basis of critical theory. Thesis Eleven, No. 5/6, s. 162-184. https://doi.org/10.1177/072551368200500112

HONNETH, A., 2010: Work and recognition: a redefinition. In: Schmidt am Bush, H.C., Zurn, C.F. (eds.): The Philosophy of Recognition: Historical and Contemporary Perspectives. Plymouth: Lexington Books, s. 223-240.

HONNETH, A., 2011: Patologie rozumu. Dějiny a současnost kritické teorie. Praha: Filosofie.

HORTON, J., 1964: The dehumanization of anomie and alienation: a problem in the ideology of sociology. The British Journal of Sociology, Vol. 15, No .4, s. 283-300. https://doi.org/10.2307/588861

HRUBEC, M., 2011: Od zneuznání ke spravedlnosti. Kritická teorie globální společnosti a politiky. Praha: Nakladatelství Filosofia.

HRUBEC, M. a kol., 2012: Etika sociálních konfliktů. Axel Honneth a kritická teorie uznání. Praha: Nakladatelství Filosofia.

ISRAEL, J. 1976: Alienation and reification. In: Geyer F., Schweitzer, D. (eds.): Theories of Alienation. Leiden, s. 41-57.

JAEGGI, R., 2014: Alienation. New York: Columbia University Press.

JAY, M., 1973: The Dialectical Imagination. A History of the Frankfurt School and the Institute for Social Research 1923 - 1950. London: Heinemann.

KON, I. S., 1967: The concept of alienation in modern sociology. Social Research, Vol. 4, No. 3, s. 507-528.

LITTLER, C. R. - SALAMAN, G., 1982: Bravermania and beyond: recent theories of the labour process. In: Sociology, Vol. 16, No. 2 , s. 251-269. https://doi.org/10.1177/0038038582016002006

MAREŠ, P., 2004: Od práce emancipující k práci mizející. Sociologický časopis, roč. 40, č. 1-2, s. 37-48. https://doi.org/10.13060/00380288.2004.40.1.03

MARX, K., 1971: Ekonomicko-filozofické rukopisy. In: Malé ekonomické spisy. 2. vydanie. Bratislava: Vydavatel'stvo politickej literatúry.

MÉSZÁROSZ, I., 1970: Marx's Theory of Alienation. Merlin Press. Fifth Edition.

MARCUSE, H., 1991: Jednorozmerný člověk. Praha: Naše vojsko. 
OLLMAN, B., 1976: Alienation. Marx’s conception of man in capitalist society. New York: Cambridge University Press. Second Edition.

SAYERS, S., 2011: Marx and Alienation. Essays on Hegelian Themes. London: Palgrave Macmillan.

SEEMAN, M., 1959: On the meaning of alienation. American Sociological Review, Vol. 24, No. 6, p. 783-791. https://doi.org/10.2307/2088565

SEEMAN, M., 1967: On the personal consequences of alienation in work. American Sociological Review, Vol. 32, No. 2, s. 273-285. https://doi.org/10.2307/2091817

SEEMAN, M., 1972: Alienation and engagement. In: Campbell, A., Converse, P.E. (eds.): The Human Meaning of Social Change. New York: Russel Sage, s. 467-527.

SEEMAN, M., 1975: Alienation studies. Annual Review of Sociology, Vol. 1, s. 91123.

SHEPARD, J., 1977: Technology, alienation, and job satisfaction. Annual Review of Sociology, Vol. 3, s. 1-21. https://doi.org/10.1146/annurev.so.03.080177.000245

SCHWEITZER., D., 1996: Fetishization of alienation: unpacking a problem of science, knowledge, and reified practices in the workplaces. In: Geyer F. (ed.): Alienation, Ethnicity, and Postmodernism. Westport: Greenwod Press, s. 21-36.

SMITH, V., 1994: Braverman's legacy. The labour process theory tradition at 20. Work and Occupations, Vol. 24, No. 4, s. 403-421. https://doi.org/10.1177/0730888494021004004

THOMPSON, M. J., 2017: Introduction: What is Critical Theory? In: The Palgrave Handbook of Critical Theory. London: Palgrave Macmillan.

WALLIMANN, I., 1981: Estrangement. Westport: Greenwood Press. 